\title{
Reservations to Treaties, Prohibited Reservations and some Unsolved Issued Related to Them
}

\author{
Fjorda Shqarri \\ Phd candidate, Faculty of Law, University of Tirana, Professor at Faculty of Law, University of Tirana, Department of Public Law \\ fjorda.shqarri@hotmail.com
}

\section{Doi:10.5901/mjss.2015.v6n2s2p97}

\begin{abstract}
The capacity of states to conclude treaties is the most important premise of their legal personality, but sometimes a state wants to be part of the treaty but also wants to exclude the effect of some provisions. The statement, however phrased or named, made by a State, when signing, ratifying, accepting, approving or acceding to a treaty, whereby it purports to exclude or to modify the legal effect of certain provisions of the treaty in their application to that State is called reservation to the treaty. This paper aims to analyze on the basis of a qualitative methodology, based on research in the literature and relevant legal acts, the role of reservations in the conclusion of treaties between states, its content, the acts similar to reservations and also the prohibited reservations. The consequences of the reservations and the relations between reserving sate and the parties of the treaty, as well as other important issues related to them.
\end{abstract}

Keywords: treaties, reservation, interpretative declaration, prohibited reservation, compatibility test

\section{General Overview of the Legal Regime of Reservations}

Article 2/1/d) of Vienna Convention "On the law of treaties" 1969 (mentioned below as Vienna Convention) defines a reservation as "a unilateral statement, however phrased or named, made by a State, when signing, ratifying, accepting, approving or acceding to a treaty, whereby it purports to exclude or to modify the legal effect of certain provisions of the treaty in their application to that State;" (Vienna Convention, art. 2) meantime the Vienna Convention of 1986 includes as subject with the right to make reservations the international organizations.

From this definition we understand that the term 'unilateral statement' means that it is done individually by the state and not in agreement with other States Parties, although some countries may make the same reservation (Aust. A, Modern Treaty Law and Practice, pg. 131). Told otherwise by a reservation into a treaty a state refuses to bound itself with an obligation arising from it, although it agrees with the rest of provisions of this treaty.

The state's ability to make reservations in an international treaty illustrates the principle of state sovereignty, whereby each state can refuse consent to be bound by specific provision and this provision cannot be obligatory to the reservation state. On the other hand, to expose a treaty to reservations of all member states, the means to put at risk all of its implementation. (Shaw. M, International Law, 6ed, Cambridge University Press, pg. 914)

We should note that reservations to a treaty are always unilateral statements, and the fact that some states may make reservation for the same article or provision, does not mean that the reservation loses its a unilateral character, because anyway reservations will be considered individually and not in group( ILC, Guide to practice, UN, 2002).

Reasons why a state wants to make reservation in an international treaty can be different depending on the interest and the politics of each state, but it does not matter for international law and the parties to the treaty. But raises the question which statements or declarations constitute reservations and what they intend to exclude? This is a question that may never get a precise and exhaustive answer because as mentioned above, always depends on the interests of each state party to the treaty, but in general we can mention some of the frequent cases of reservations.

Referring Guide to Practice for reservations in the Treaties of the International Law Commission of UN, "any unilateral statement drafted by a state or international organization through which aim to limit the obligations imposed by the treaty constitutes reservation". Also will be considered as a reservation each statement made by the parties to the treaty at the time of its ratification, acceptance, approval or accession that it intends to implement the obligations deriving from the treaty in a different manner, but considered by the author of the statement as equivalent to those stipulated by the treaty ( ILC, Guide to practice on reservations to treaties, UN, 2011). 


\section{Types of Reservations}

Reservations may also be related with territorial application of international treaties. Specifically, the unilateral declarations made by a state by which it intends to exclude the application of certain provisions of the treaty or the entire treaty in a part of its territory for specific reasons constitute reservations. Also unilateral declarations intended to change or modify the effect of certain provisions of the treaty in a part of this state territory constitutes reservation of the treaty in question (ILC, Guide to practice on reservations to treaties, UN, 2011).

Although, both of these cases may appear very similar, it must be said that the purpose that is aimed by the reservation state is different, because in the first case the aim is to exclude a part of the territory from the obligations arising from the treaty, while in the second case the goal of the state is to modify the effects that will bring the treaty in a specific part of its territory.

Depending of the moment of their expression during the concluding treaty process, reservations can be divided in reservations at the time of signature, reservations at the time of ratification and at the time of accession (Puto. A, Public International Law).

Reservations at the signing time are easier to be accepted, because at this moment the parties are aware of the obligations and rights that will connect them reciprocally, while at the time of ratification of this issue differs because it did not leave the parties the opportunity to modify the treaty provisions, putting them forward an unexpected situation. At the moment of ratification is presumed that all parties are waiting the entry into force of the treaty to implement it, and if at this point a reservation is made this mean that this may prevent or in the best case may suspend or postpone the time of entry force.

However it must be said that it may have also late reservations, which are made upon ratification, and in this case the depositary state notify all parties to the treaty for the formulation of such reservation records it, no other State has raised objections (UN, Treaty handbook, pg. 12).

It should be mentioned here that there is a distinction between reservations in bilateral and reservations in multilateral treaties. Although the Vienna Convention itself makes no distinction between them, the fact is that these two cases have different consequences. So a reservation in the meaning of art 2/1/d of VC cannot be made to a bilateral treaty because this kind of treaty needs that both parties agreed for all terms before it can be bind to them.

In this sense, the International Law Commission of the United Nations declared that a state declaration regarding a provision of a bilateral treaty made before the entry into force of the Treaty, irrespective of its formulation, which requires modification of the legal effect the provision, cannot be called reservation (ILC, Guide to practice 2011). Such argumentation is thought to be based precisely on the fact that in bilateral treaties, when one of the parties does not accept the treaty or some provisions made by it, then there is no agreement (Shaw. M, International law, CU Press 6ed) and in this case and is required reopening of negotiations to modify the terms of the agreement, otherwise the treaty will not be signed.

While in multilateral treaties, seems that the need for reservations is derived from the nature and process of their formulation. Usually, in such treaties are part of a large number of states, which represent different systems of law, different geographical regions, and what are most important different policies, so it is understandable that they may not agree with specific provisions of the treaty, which could conflict with their domestic policy.

Reserves at the time of accession are common and have been applied in many multilateral treaties. The concept of accession as a legal act whereby a not treaty party State, join in on a later moment of its entry into force (Puto. A, Public International Law, pg. 376), makes it clear that such reservation does not affect the legal poker and the implementation of the treaty. On the other hand, it is normal that such reservations are the most common, considering the fact that a later member state, has not participated in the negotiation phase and has not had the opportunity to express his opinion or position regarding treaty's provisions.

\section{Interpretative Declarations and other Acts Similar to Reservations}

Apart proper reservations in treaties, we have also acts similar to them, which depending by the case may or may not have the reservation legal effect. So, we have political declarations and interpretative declarations.

Political declarations are made by states when they sign a treaty, but do not intend to have any concrete effect regarding the treaty in question. Generally these kinds of declarations are mostly related with issues of domestic policies of a state and do not affect either the application or other member parties to the treaty, such as declarations that although the state has signed the treaty that does not mean that it recognizes the states party to (Aust. A, Modern Treaty law and practice, pg. 129), which he has not recognized individually, or declarations by which a State makes known his position 
on certain issues related to the other parties to the treaty.

Interpretative declarations are unilateral declaration of a state or international organization party to a treaty, by means of which they intend to specify or clarify the meaning or purpose of the treaty or its particular provisions (ILC, Guide to practice on reservations to treaties, 2011). As mentioned above, the fact that such statements can be made from several states jointly, this does not mean that they lose their unilateral character.

However, it should be mentioned that the main difference between these declarations and reservations is their legal effect, as it is known the reservation effect is to modify the treaty while these kinds of declarations do not produce effects for other parties (except specific cases). Still, interpretation in good faith of the title, text and purpose of the statement is the one that makes the difference whether it's an interpretative statement or a reservation (ILC, Guide to practice on reservations to treaties, 2011).

So, in the "Continental Shelf France - United Kingdom" case, the court has referred to the Convention on the Continental Shelf in 1958, were both states were parties and where France had made a reservation for the implementation of the article $6^{1}$. The arbitral tribunal dismisses claims of United Kingdom that it is a simple interpretive statement, arguing that although this statement has elements of interpretation, its aim is to exclude or modify the legal effect of certain provisions of the treaty, and therefore it makes backup (Sh. Malcolm, International law, 6ed, 2008, pg. 916).

Although an interpretive statement has not legal effects for other parties to the treaty, it must be said that often "hide" in itself a reservation to a treaty provision. Therefore we can say that many authors make the difference between simple interpretative declarations and qualified interpretative declarations where the qualified interpretative declarations in certain situations can bring the effects of reservations (Sh. Malcolm, International law, 6ed, 2008, pg. 916).

Usually, when a treaty prohibits reservations, interpretative declarations cannot be called as such, however in special situations when they intend to exclude or modify the legal effect of certain provisions of the treaty, or the treaty as a whole in relation to certain specific aspects in their application to its author, may constitute a reservation. A declarations can be considered as qualified if it makes interpretation of the treaty or its provisions and in this case should be used all the rules that are in force for reservation in international treaties (ILC, Guide to practice on reservations to treaties, 2011).

In the case of bilateral treaties it must be said that interpretative declarations made by one party and accepted by the other party constitutes the authentic interpretation of this provision or of the treaty.

Also, there may be cases when the treaty provides for the states parties the right to make interpretative declarations and in some treaties is provided as obligations to make these declarations. Such declarations are optional when the treaty expressly permits the party to make interpretative declarations if this is necessary, and interpretative declarations are binding on those occasions when the treaty explicitly requires such a thing. For example we can mention here the Montego Bay Convention 1982, which provides that States Parties should make declarations about how will be applied the Convention to each of them and how to harmonize domestic law with the Convention (UN, Treaty handbook). We can also mention cases when the treaty demands to know the minimum age of the subjects to which they apply its effects, etc.

Interpretative declarations can be made as to the time of signature, ratification, acceptance, approval or later and there be no prescribed form of how it must be drafted. However, in those cases when optional interpretative declaration establish obligations to the state party or organization, then it should be signed by the competent state authority, or the person authorized by full power.

Usually Depositary State shall notify all parties of interpretative declarations made to a treaty, and if other states suspect that we are dealing with a reservation since the statement is intended to modify the legal effects of the treaty, then they have the right to object this declaration.

In cases where the treaty prohibits reservations, the states can be addressed to the other options that aim to avoid the full effect of the treaty. Such may be clauses in the treaty intended to limit the scope of it, or conclusion of parallel agreements with one or more parties to the treaty in which is provided that between them they will not apply one or more provisions of the treaty. Also, a part of the interpretative declarations, states or international organizations may claim to formulate treaty clauses for interpretation or conclusion of a special agreement for this purpose (ILC, Guide to practice on reservations to treaties).

\section{Prohibited Reservations}

The permissibility of a reservations to an international treaty is a very important issue, because on the one hand is the will

1 In this case France ask to implement the equidistance principle 
to maintain the 'integrity' of a treaty in order that parties be related equally with his rights and obligations, on the other hand is purpose is to ensure a wider participation of the parties even if they do not accept all treaty's provisions. Especially, this need is felt to treaties that establish certain standards or general principles (For example ECHR or Montego Bay Convention), however, in such cases there are restrictions on the right to make reservations (Dixon. M, McCorquordale. R, Williams. S, Cases and materials on international law, 5ed, Oxford press)

Article 19 of Vienna Convention provides that states have the right to make a reservation at the time of signing, ratifying, accepting, approving or acceding to a treaty, which means that firstly this right is limited in time (UN, $10^{\text {th }}$ report of ILC, Reservations to treaties), (as we have mentioned above). However, this is not the only limitation, as this article provides that reservations in a treaty cannot be made in cases where the treaty itself prohibits reservations. So, when the treaty provision provides that reservations are prohibited, the treaty should enter into force between the parties or they should reconsider their positions regarding participation in this treaty.

Prohibited reservations means all cases when the treaty itself prohibits all kind of reservation, cases when the treaty prohibited reservations regarding specific provisions and a state party want to make a reservation for the provision in question, and cases when the treaty prohibits a category of reservations (UN, Guide to practice).

The Convention also provides that no reservations may be made in those cases where the treaty itself allows specific reservations, but reservations made by a party cannot be included in this category. Specific reservations mean those specifically mentioned to the treaty as permissible, which are related to certain provisions of the treaty.

More specifically, a treaty may contain predictions that parties may exclude from the application of the treaty some subjects or issues. Also the treaty can provide that reserves are allowed only on some provisions, for example, provisions relating to the settlement of disputes or the interpretation of the treaty. A treaty may also provide that reservations can be made only to certain rights and obligations (Aust. A, Modern Treaty law and practice, pg. 136)

The Convention also provides that are not permitted reservations which are contrary to the purpose and object of the treaty. We can say that this prediction is somewhat vague, since there is no real definition of criteria when will be considered that the reserve is related to the object or purpose of the treaty, especially if the treaty is silent on reservations, the test of compatibility becomes more difficult (Aust. A, Modern Treaty law and practice, pg. 137).

However we can say that this is an issue the interpretation of which must be made under the principle of good faith and referring general terms of the treaty, title, preamble, negotiation and practice of the party before the conclusion of the treaty. Reservations should be formulated in such a way that its content is understandable and allow compatibility testing (UN, Guide to practice).

However, in general terms a reservation can be considered not to comply with the object and purpose of the treaty if it affects the essential elements of the treaty or the reason for which it was created or compiled.

As to assess the compatibility of a reservation with the purpose and object of a treaty that contains many interdependent rights and obligations should be taken into account as well interdependence, the importance of the provision to which the reservation is made in the general context of the treaty and the impact that the reservations has on the treaty (UN, Guide to practice).

The issue of reservations which are incompatible with the object and purpose of the treaty is actually very controversial, especially when it comes to human rights treaties. In Guide to Practice of International Law Commission of United Nations is mentioned that is prohibited a reservation to a provision that provides a right that no derogation is permitted, unless these reservations are in compliance with the essential rights and obligations arising from this treaty.

If a state aims through the reservation, to change the legal effect of the treaty or its provisions with the justification that want to preserve the integrity of the domestic law, this reservation is permitted only if it does not affect the essential elements and the general concept of the treaty (UN, Guide to practice).

While there may be regarded as prohibited a reservations made on the provisions of the treaty that reflect norms of customary law or the provisions relating to supervisory bodies for the implementation of the treaty or the settlement of disputes. We also should mention here that is not permissible a general reservation, because a reservation should be made always in regard of specific provision, signing or ratification lose it role.

The authorities which can examine the permissibility of a reservation can be the states or organizations party to a treaty, can be bodies created by the treaty to resolve disputes, or monitoring bodies created for the implementation of the treaty. In cases when the treaty establish a body to resolve disputes of the parties, and in a concrete case the dispute relates to the permissibility of the reservation, then such a body is entitled to examine the permissibility and decision that he gives is binding on the parties (UN, Guide to practice). 


\section{Some Unsolved Issues Related to Reservations}

However, remains unresolved issue of entry into force of the reserves, as if we refer to article 20/4 of Vienna Convention, it is foreseen that a reservation made by a State may be considered accepted if it is accepted at least by one state party to the treaty, and the objection from another state of a reservation does not preclude the entry into force of the treaty between objecting states reserving status, except when such a thing is expressly specified. On the other hand, this article is silent on the nature that reservations must have to be accepted, so it does not what will happen if a reservation is not compatible with the article 19 of the Convention and is accepted by the parties to the treaty.

Regarding Article 19, special issue presents article 19/c as the conventions are silent regarding the compatibility test and its objectivity. So there is no well-defined criteria based on which the compatibility test of the reservation with the object and purpose of the treaty will be made, leaving the parties assessing this issue.

Also is not clear the status of a state that makes a reservation prohibited by Article 19 , will it be considered as a party to the treaty without taking into account the reserve and which will be the respective rights and obligations in this case? Or it will not be considered as a party to the treaty? Especially, this situation is important to be clarified in the cases when the state authorities relate the ratification of the treaty with the reservations.

As a conclusions we can say that: Reservation in multilateral treaties are a good way to expand participation in the treaty as well as to satisfy all its member states, which may belong to different legal systems. Whether treaty reservations are prohibited, then international law itself has put the parties in other available legal remedies that may have the same effects. But Vienna Convention on the law of treaties is not clear in some of its provisions regarding permissibility of reservation, compatibility test and entry into force of reservations. Also the consequences for the state that made the prohibited reservation are not specified.

\section{References}

Vienna Convention "On the law of Treaties" 1969

ILC, Guide to practice, UN, 2002

ILC, Guide to practice on reservations to treaties, UN, 2011

UN, Treaty handbook,

UN, 10 th report of ILC, Reservations to treaties

Aust. A, Modern Treaty Law and Practice

Shaw. M, International Law, 6ed, Cambridge University Press

Puto. A, Public International Law

Dixon. M, McCorquordale. R, Williams. S, Cases and materials on international law, 5ed, Oxford press 
